\title{
AL-AWQAF
}

Jurnal Wakaf dan Ekonomi Islam

Vol. 13, No. 2, Tahun 2020

\section{Membangun Awareness Muslim Milenial Terhadap Donasi Berkelanjutan Melalui CWLS}

\author{
Fatimah Khoirun Nisa ${ }^{1}$, Lintang Titian Purbasari ${ }^{2}$ \\ 1,2 Universitas Airlangga, Surabaya
}

\begin{abstract}
The purpose of this research is to increase awareness about a new, smarter, and more sustainable way to donate to the millennial generation through Cash Waqf Linked Sukuk (CWLS). Using literature study approach, this research reviews various facts that create opportunities for CWLS development in Indonesia and theories from previous researches regarding to the importance of awareness stages in the process of adopting new products. Criticism is also conveyed in this article regarding to the lack of socialization regarding CWLS, whereas the enormous development impact as the result if the CWLS instrument gets great attention from the public, especially investors. The use of social media and influencers is suggested in this article as a tool to increase awareness of the millennial generation about the benefits of CWLS products which can later increase the number of investors among millennials.
\end{abstract}

Keywords: awareness, CWLS, millennials, social media.

Abstrak: Tujuan dari penelitian ini adalah untuk meningkatkan awareness mengenai cara baru berdonasi yang lebih cerdas dan berkelanjutan kepada generasi milenial melalui Cash Waqf Linked Sukuk (CWLS). Dengan pendekatan studi literatur, penelitian ini mengulas berbagai fakta yang menciptakan peluang pengembangan CWLS di Indonesia dan teori dari penelitian terdahulu mengenai pentingnya tahapan awareness dalam proses pengadopsian produk baru. Kritikan juga disampaikan dalam artikel ini mengenai kurangnya sosialisasi mengenai CWLS, mengingat begitu besarnya dampak pembangunan yang dihasilkan jika instrumen CWLS mendapatkan perhatian yang besar dari masyarakat, khususnya investor. Pemanfaatan media sosial dan influencer disarankan dalam artikel ini sebagai alat untuk meningkatkan kesadaran generasi milenial tentang seberapa besar manfaat dari produk CWLS yang nantinya dapat meningkatkan jumlah investor dari kalangan milenial.

Kata Kunci: awareness, CWLS, milenial, media sosial.

$$
\begin{aligned}
& \text { ملخص: يستهدف هذا البحث إلى زيادة الوعي حول طريقة جديدة التي هي أذكى أدوم للتبرع لدى جيل الألفية } \\
& \text { من خلال الصكوك المرتبطة بالوقف النقدي(CWLS) . وباستخدام منهج دراسـة الأدبيات، يستعرض هذا } \\
& \text { البحث الحقائق المختلفة التي تحدث فرصًا لتطوير CWLS في إندونيسيا والنظريات من الأبحاث السابقة فيما } \\
& \text { يتعلق بأهمية مراحل التوعية في عملية تبني المنتجات الجديدة. يتم نقل النقد أيضًا في هذه المقالة فيما يتعلق } \\
& \text { بنقص التنشئة الاجتماعية فيما يتعلق بـCWLS ، في حين أن التأثير الإنمائي الهائل نتيجة لذلك إذا لذا حظيت }
\end{aligned}
$$

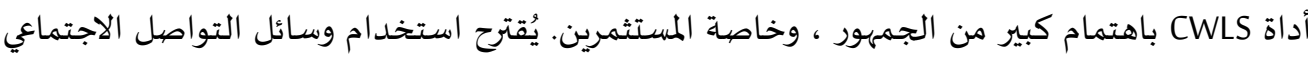




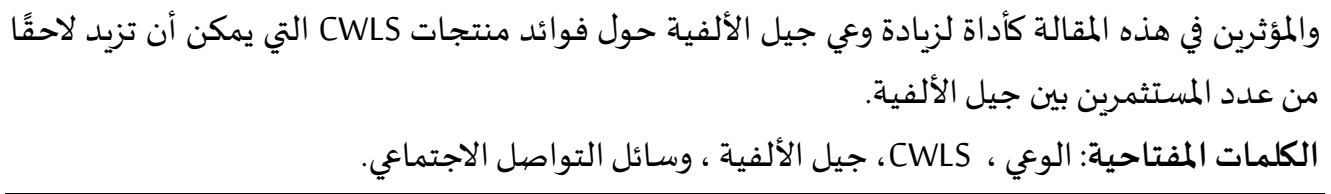

\section{Pendahuluan}

Indonesia sempat dinobatkan sebagai negara paling dermawan berdasarkan hasil survei yang dilakukan oleh Charities Aid Foundation (CAF) pada tahun 2018. Menyusul datangnya berbagai kejadian yang sangat mengguncang perekonomian Indonesia seperti adanya wabah covid-19, ternyata tak menggoyahkan semangat masyarakat Indonesia untuk terus berdonasi. Hal tersebut dibuktikan dengan hasil terbaru dari penelitian yang dipublikasikan dalam edisi khusus peringatan ke 10 CAF's World Giving Index. Dalam edisi tersebut terdapat data dari negaranegara teratas dan terbawah yang dikumpulkan selama 10 tahun dan Indonesia termasuk dalam peringkat 10 teratas. Walaupun masuk dalam peringkat 10, namun sebagaimana dilansir dari laman covid19 filantropi.id Indonesia merupakan satu-satunya negara di daftar 10 terbesar dengan skor yang terus meningkat, sementara negara lain mengalami menurun. Dari hasil survei tersebut dapat menggambarkan bahwa mayoritas masyarakat Indonesia gemar berdonasi.

Kegemaran berdonasi dari masyarakat Indonesia ini ternyata didominasi oleh generasi milenial. Hal tersebut dibuktikan dengan hasil survei yang dilakukan oleh Kopernik dan Gopay selama Agustus hingga Oktober 2020 yang menyatakan bahwa generasi milenial paling sering berdonasi terutama donasi melalui platform digital. Menyambung hasil laporan tahunan CAF's World Giving Index (WGI) edisi ke-10 di mana terdapat tiga aspek yang dinilai untuk menentukan seberapa dermawan suatu negara yakni membantu orang asing, menyumbangkan uang ke lembaga amal, dan mengikuti kegiatan amal secara sukarela, dari ketiga aspek tersebut, masyarakat yang menyumbang uang ke lembaga amal mendominasi dengan persentase sebesar 69\%. Dengan begitu dapat dikatakan bahwa hobi berdonasi didominasi oleh milenial dan sebagian besar dari mereka menyumbangkan dana mereka melalui lembaga amal yang ada di Indonesia.

Selain menghasilkan data bahwa milenial sebagai generasi yang hobi menabung, Kopernik dan Gopay dalam hasil surveinya yang dikutip dari laman money.kompas.com juga menyebutkan bahwa alasan mereka untuk berdonasi dilandasi oleh nilai sosial dan nilai agama. Dengan kata lain niat membantu sesama mendominasi alasan mereka untuk berbagi, disisi lain nilai agama pun juga menjadi alasan mereka dalam berdonasi. Berkaitan dengan agama, sebagai negara dengan mayoritas penduduknya memeluk Islam, pengaruh ajaran Islam di mana berbagi merupakan perintah bagi umatnya juga tidak bisa dikesampingkan. Bicara mengenai perintah berbagi, Islam sendiri memiliki beberapa instrumen pendanaan sosial, salah satunya adalah wakaf. Dalam sejarahnya, Wakaf telah memainkan peran penting dalam membangun peradaban Islam (Musari, 2019). Penelitian terdahulu (Çizakça, 1998; Sulaiman, Adnan \& Nor, 2009; Ali, 2014; Ahmad, 2015; Sanrego \& Taufik,2016 dalam Musari, 2019) juga banyak menyatakan bahwa wakaf merupakan instrumen penting dalam menurunkan tingkat kemiskinan, memulihkan sosial ekonomi umat Islam, dan mewujudkan keadilan dalam pemerataan distribusi kekayaan di masyarakat. Dengan keandalan yang dimiliki banyak 
cendekiawan maupun ekonom muslim yang berusaha mengembangkan model praktik perwakafan guna memaksimalkan potensi yang dimilikinya.

Masalah yang tengah dihadapi dunia perwakafan saat ini salah satunya mengenai rendahnya tingkat awareness tentang wakaf. Berdasarkan informasi yang bersumber dari Masterplan Ekonomi Syariah Indonesia 2019-2024 banyak masyarakat yang masih terjebak pada terminologi lama wakaf, di mana umumnya wakaf berbentuk tahan atau pemanfaatannya yang sebatas untuk lingkup sosial seperti tanah makam atau ibadah seperti pembangunan masjid. Awareness mengenai terminologi kontemporer yakni penerapan wakaf uang masih rendah. Padahal jika merujuk pada Çizakça (2014), keuangan Islam sudah seharusnya melakukan inovasi guna menghadapi dunia yang dinamis dan mengalami perkembangan yang sangat cepat untuk menghindari sistem keuangan yang usang dan stagnan.

Menanggapi kebutuhan akan inovasi tersebut, pihak instansi wakaf yakni BWI telah berjuang keras melakukan berbagai inovasi dalam dunia perwakafan yakni salah satunya dengan meluncurkan produk Cash WaqfLinked Sukuk (CWLS). Produk tersebut merupakan terobosan baru dalam pemanfaatan wakaf guna menjangkau dampak yang lebih luas, terkhusus untuk pembangunan sosial ekonomi masyarakat Indonesia. Oleh karena itu, dalam makalah ini penulis ingin mengangkat pembahasan mengenai peningkatan awareness tentang cara baru berdonasi kepada kalangan milenial yang lebih cerdas dan berkelanjutan melalui CWLS. Di sisi lain, pembahasan mengenai betapa pentingnya pengembangan cara untuk meningkatkan awareness sebagai tahap awal dalam proses pengadopsian suatu produk atau jasa sangat minim di bahas. Dalam makalah ini penulis menggunakan pendekatan teoritis guna memberikan gambaran serta ide konsep yang dapat dijadikan dasar untuk dapat diteliti lebih dalam pada penelitian selanjutnya.

\section{Kajian Pustaka}

\section{Konsep Wakaf dan Wakaf Uang}

Wakaf berasal dari kata Arab yaitu waqafa yang secara harfiah berarti menahan atau berhenti untuk tujuan tertentu. Islam menjadikan wakaf sebagai bentuk pemberian dari Allah yang ditujukan untuk kesejahteraan umat. Kahf (2014) mendefinisikan wakaf dari perspektif ekonomi sebagai pengalihan dana dari donatur kepada asset produktif yang memberikan hasil atau pendapatan untuk konsumsi masa depan oleh individu atau kelompok. Dalam hadits Nabi Muhammad SAW, wakaf disebut sebagai sadaqaton jariyah atau amal yang berkelanjutan. Pada masa Rasulullah, wakaf kebanyakan berupa properti, seperti masjid, sumur, tanah dan kuda yang mana dapat digunakan untuk penggunaan umum.

Menurut mazhab Syafi'i, ketika sebuah properti dijadikan wakaf, kepemilikan properti tersebut dialihkan kepada Allah, dan karenanya tidak ada hak yang sah bagi pemberi wakaf (wakif) atau ahli waris (mawqouf alayh). Namun, menurut mazhab Maliki dan Hanbali, dengan memberikan properti sebagai wakaf, pemberi kuasa mengalihkan kepemilikan kepada penerima. Sedangkan menurut mazhab Hanafi, harta wakaf boleh dijual. Tanah subjek wakaf tidak dapat dialihkan, tidak untuk diberikan, tidak untuk diwariskan dan manfaatnya harus digunakan untuk orangorang miskin, kerabat pemberi wakaf, budak, pelancong dan tamu. Para wali (mutawalli atau 
nazhir) dapat memanfaatkan hasil pendapatan dari produktifitas tersebut untuk memberi makan yang membutuhkan (Salleh et al., 2020).

Konsep Wakaf tidak disebutkan secara spesifik dalam Al-Qur'an. Namun, Allah telah menyebutkan dalam Al-Qur'an konsep sedekah yang tinggi melalui sumbangan (Chowdhury et al., 2011). Dalam Surah al-Baqarah ayat 271 di bawah ini, Allah SWT telah mengakui pahala bagi orang yang bersedekah untuk membantu sesama terutama orang miskin.

"If you disclose your charitable expenditures, they are good; but if you conceal them and give them to the poor, it is better for you, and He will remove from you some of your misdeeds [thereby]. And Allah, with what you do, is [fully] Acquainted" (QS. 2: 271).

Karena tidak ada singgungan langsung tentang wakaf dalam Al-Qur'an, maka hadits Nabi Muhammad SAW berikut ini pada dasarnya menjelaskan konsep Wakaf. Dalam sebuah hadits yang diriwayatkan oleh Abu Hurairah, Rasulullah bersabda:

"When a son of Adam dies, so does their deeds except for three things: alms giving, or benefited knowledge, or pious son who pray for them" (Muslim, Tarmidhi, Abu Dawud, Nasa'i and Ibn Majab).

Wakaf uang merupakan salah satu jenis wakaf dimana modal wakafnya adalah uang uang. Diadakannya wakaf uang memiliki tujuan tertentu, yaitu menjadi modal wakaf yang dioperasikan dengan metode Islam, dan pendapatan yang diperoleh dari operasi tersebut digunakan untuk memenuhi keperluan wakaf (Bulut dan Korkut, 2016). Lembaga wakaf telah banyak digunakan oleh umat Islam sejak abad pertama Islam untuk berbagai keperluan, antara lain pendidikan, pembangunan masjid dan sekolah, pengasuhan anak yatim dan janda serta masih banyak lagi kegiatan lainnya untuk kemajuan masyarakat. Namun, Ottoman memperkenalkan model wakaf uang pada abad ke-15 dan berkembang pada abad-abad berikutnya di seluruh bagian kekaisaran.

Di Indonesia, wakaf uang diatur dalam Fatwa MUI tahun 2002. Menurut fatwa tersebut, wakaf uang adalah wakaf yang dapat dilakukan oleh seseorang, kelompok, lembaga atau badan hukum berupa uang tunai yang didalamnya termasuk surat berharga. Kemudian hukum wakaf uang adalah jawaz (diperbolehkan) selama dananya disalurkan dan digunakan untuk tujuan yang diperbolehkan dalam syariah. Selain itu, nilai pokok wakaf uang harus dijamin. Menyusul terbitnya Undang-Undang Nomor 41 Tahun 2004 tentang wakaf, pemerintah mengeluarkan Peraturan Pemerintah Nomor 42 Tahun 2006 yang secara jelas mengakui bahwa wakaf benda bergerak termasuk wakaf uang.

\section{Cash Waqf Linked Sukuk}

Cash Wakaf Linked Sukuk (CWLS) atau wakaf uang link sukuk merupakan inovasi dan terobosan wakaf uang serta investasinya. Cash Wakaf Linked Sukuk (CWLS) adalah salah satu program perwujudan wakaf produktif dari Badan Wakaf Indonesia yang bekerja sama dengan kementerian Keuangan dan Bank Indonesia sebagai fasilitator. Cash Wakaf Linked Sukuk (CWLS) berbentuk investasi sosial di Indonesia, dimana wakaf uang yang dikumpulkan oleh Badan Wakaf Indonesia selaku Nazhir melalui Bank Muamalat Indonesia dan BNI Syariah sebagai Lembaga Keuangan Syariah Penerima Wakaf Uang (LKSPWU) akan dikelola dan 
ditempatkan pada instrumen Sukuk Negara atau SBSN (Surat Berharga Syariah Negara) yang diterbitkan oleh Kementrian Keuangan (Kemenkeu) dengan jangka waktu 5 tahun. Keunikan program Cash Wakaf Linked Sukuk adalah penyetor wakaf atau wakif dapat dilakukan oleh perorangan, komunitas atau lembaga dan dapat berwakaf secara temporer dengan minimal Rp 3 juta dan minimum jangka waktu 5 tahun. Program tersebut melibatkan 5 stakeholders, yaitu Bank Indonesia sebagai fasilitator, Bank Wakaf Indonesia (BWI) sebagai nazhir yang mengelola CWLS, dan Kementerian Keuangan berperan sebagai pengelola dana di sektor riil.

Perolehan bagi hasil dari sukuk akan digunakan oleh BWI untuk program sosial yang bertujuan untuk kesejahteraan dan kemartabatan Indonesia. Misalnya, untuk beasiswa putra atau putri masyarakat di daerah terdampak bencana maupun untuk proyek-proyek wakaf yang dimiliki oleh BWI lainnya, seperti rumah sakit mata Achmad Mawardi Serang. Cash Wakaf Linked Sukuk diharapkan dapat menjadi salah satu mesin yang dapat mengubah potensi wakaf menjadi manfaat yang terus mengalir untuk kesejahteraan umat (BWI, 2019).

\section{The Hierarchy of Effects Model}

Sering kali konsumen dalam membuat keputusan menjadi tidak terkendali karena adanya informasi yang berlebihan. Oleh karena itu, mereka mengembangkan kebiasaan tertentu dan "heuristik", yang menjadi jalan pintas dan aturan praktis serta digunakan dalam pengambilan keputusan untuk mengatasi beban mental yang berlebihan (Jacoby et al., 1977; Jacoby, 1984). Merek menjadi salah satu hal yang penting karena dapat mempengaruhi pengambilan keputusan konsumen dan membimbing konsumen dalam proses pengambilan keputusan pembelian. Sehingga akan menghubungkan mereka pada keputusan saat ini dan masa depan dengan pengalaman, kepuasan, dan pengetahuan (Keller, 2008; Kapferer, 2008). Proses pengambilan keputusan konsumen terdiri dari beberapa langkah yang dilalui konsumen saat membuat keputusan pembelian (Olshavsky dan Granbois, 1979). Proses ini mencakup semua langkah dari pengenalan kebutuhan melalui pencarian sebelum pembelian untuk informasi tentang cara potensial untuk memenuhi kebutuhan, evaluasi opsi alternatif untuk pembelian aktual dan proses pasca pembelian termasuk pengalaman dan evaluasi produk.

Sejalan dengan kerangka proses pengambilan keputusan, model hierarki efek (HOE) dalam komukasi dan periklanan berfokus pada tahapan mental dari hubungan konsumen dengan produk atau merek tertentu (Vakratsas dan Ambler, 1999). Hierarki efek mengacu pada urutan tetap di mana konsumen mempersepsikan, memproses, dan menggunakan iklan dan informasi komunikasi pemasaran lainnya: pertama secara kognitif (berpikir), kedua secara afektif (perasaan), dan ketiga secara konatif (melakukan) (Barry dan Howard, 1990). Artinya konsumen awalnya memperoleh kesadaran dan pengetahuan tentang suatu produk, kemudian mengembangkan perasaan positif atau negatif terhadap produk dan akhirnya bertindak dengan membeli dan menggunakan atau dengan menolak dan menghindari produk (Kotler dan Bliemel, 2001). Sehingga dapat diimplikasikan bahwa efek sebelumnya memiliki dampak yang lebih kuat pada pengambilan keputusan konsumen (Vakratsas dan Ambler, 1999).

Hierarki yang paling banyak dikenal dan sering diterapkan secara luas adalah model dari Lavidge dan Steiner (1961). Model mereka mencakup tujuh fase yaitu ketidaksadaran, kesadaran, pengetahuan, kesukaan, preferensi, keyakinan dan pembelian. Di awal proses 
model, konsumen membentuk kesadaran sederhana setelah sebelumnya tidak menyadari merek. Selanjutnya, konsumen menerima (misalnya melalui iklan atau mulut-ke-mulut) atau mencari informasi terkait merek untuk membangun pengetahuan tentang penawaran merek. Setelah tahap berpikir, konsumen memutuskan di tahap afektif jika konsumen menyukai produk atau tidak dan membangun preferensi berdasarkan sikap yang disukai atau tidak disukai terhadap merek. Pada tahap akhir afektif, konsumen mengembangkan keyakinan akan kegunaan pembelian, yaitu niat untuk membeli. Meskipun loyalitas tidak termasuk bagian besar dari model HOE, namun idealnya mengikuti fase pembelian (Smith et al., 2008).

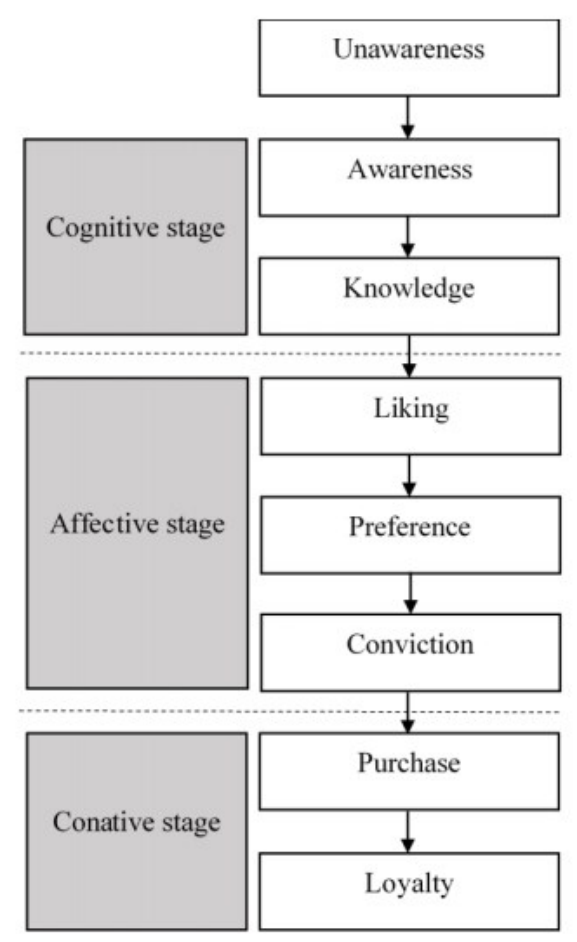

Gambar 1. Hierarchy of Effects Model (HOE), Lavidge dan Steiner (1961)

Penentu urutan dan aliran langkah tunggal dalam proses keputusan adalah keterlibatan konsumen terhadap produk atau merek. Menurut Zaichkowsky (1985) keterlibatan didefinisikan sebagai relevansi yang dirasakan seseorang dari objek berdasarkan kebutuhan, nilai, dan minat yang melekat dan bergantung pada faktor situasional. Terkait dengan proses pengambilan keputusan, keterlibatan dapat mempengaruhi HOE dalam dua cara. Pertama, bergantung pada tingkat keterlibatan, konsumen membutuhkan jumlah waktu yang berbeda untuk melewati fase (Lavidge dan Steiner, 1961). Kedua, tingkat keterlibatan berpotensi juga mempengaruhi urutan tahapan HOE (Kotler dan Bliemel, 2001; Barry dan Howard, 1990). Rendahnya keterlibatan produk pada fase afektif dan konatif dapat mendahului kognitif karena konsumen tidak "berpikir" ketika membeli produk tetapi membangun sikap setelah pembelian pada tahap penggunaan. Karena penelitian ini menyelidiki tingkat kesadaran untuk melakukan donasi yang berkelanjutan melalui CWLS, kondisi pemrosesan yang mendasari dapat dilihat sebagai sistematis dan sejalan dengan urutan HOE (Smith et al., 2008). 


\section{Kerangka Konseptual}

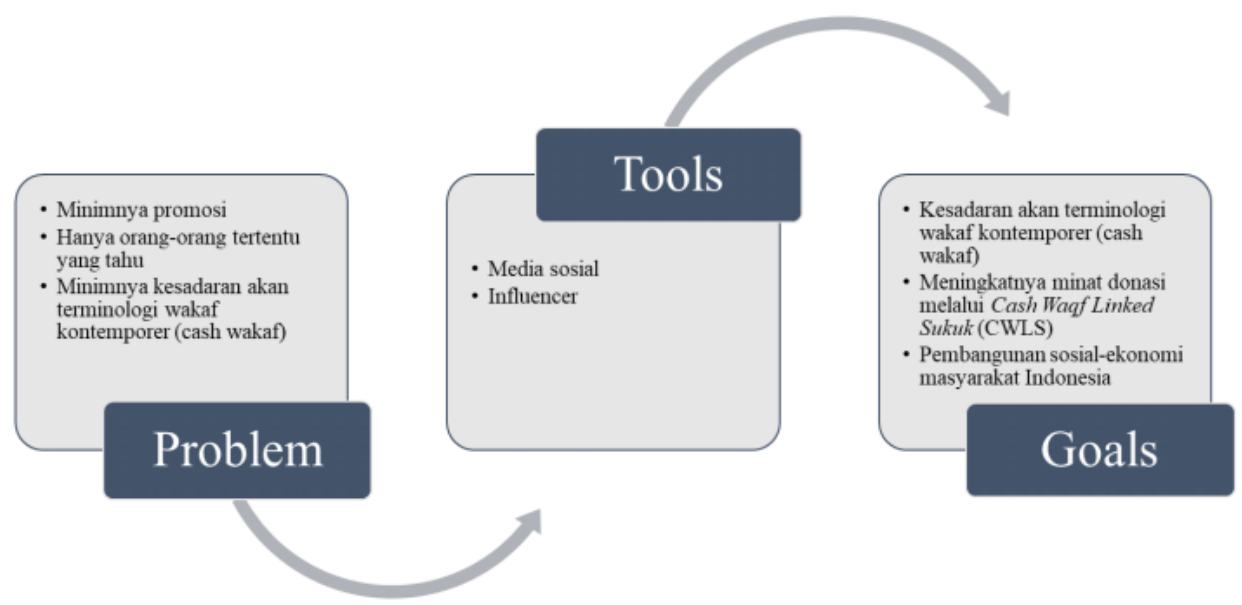

\section{Metode Analisis Data}

Penelitian ini menggunakan metode kualitatif deskriptif dengan pendekatan library research/documentary research, yaitu dengan mendeskripsikan tentang hasil amatan dari objek penelitian (Tight, 2019; Soeherman, 2019; Sugiyono, 2017). Pendekatan library research/documentary research terhadap literatur-literatur kepustakaan yang berhubungan dengan objek penelitian (Tight, 2019). Literatur tersebut berupa jurnal hasil penelitian, buku, majalah, berita dari media massa baik online maupun offline serta sumber kepustakaan lainnya yang dianggap relevan dengan tema penelitian.

\section{Hasil dan Pembahasan}

\section{Awareness}

Awareness atau kesadaran menyiratkan pengetahuan yang diperoleh melalui persepsi seseorang atau informasi dari luar mengenai suatu hal (Gupta, 2021) yang dalam hal ini adalah mengenai CWLS dan berbagai ruang lingkup yang menyertainya. Dalam hal ini, awareness dapat dikatakan sebagai langkah awal bagi seseorang dalam memutuskan sesuatu. Merujuk pada model "bierarchy of effect" (HOE) yang telah diulas sebelumnya, hierarki efek mengacu pada urutan tetap mengenai bagaimana seorang konsumen mempersepsikan, memproses, dan menggunakan suatu informasi suatu produk yang diawali dengan tahapan kognitif (berpikir), di mana dalam model digambarkan bahwa awareness merupakan bagian awal dalam tahap kognitif (berpikir).

Dari model "bierarchy of effect" (HOE), dapat kita pahami bahwa awareness merupakan tahap yang penting dan utama dalam proses penerimaan suatu produk atau jasa oleh konsumen. Apabila proses tersebut terlewat atau tidak mendapatkan perhatian dari pemasar, maka proses pengenalan produk terutama produk baru tidak dapat berjalan optimal. Mendukung model tersebut, dalam penelitian lain (Emanuel dan Adams, 2011; Cotton dkk., 2016 dalam Cogut, dkk., 2019) pada konteks perubahan perilaku yang mendukung sustainability untuk menjaga keseimbangan alam, awareness memiliki peranan yang cukup mendasar karena untuk memahami perilaku sustainability, individu pertama-tama harus menyadari ide dan praktik tersebut, dan jika 
pada tahapan kesadaran ini gagal maka akan sulit untuk melakukan perubahan perilaku sustainability untuk jangka panjang. Jadi, untuk terciptanya perubahan perilaku berdonasi yang lebih cerdas dan berkelanjutan melalui CWLS, meningkatkan kesadaran merupakan langkah pertama karena kebanyakan orang tidak terbiasa dengan konsep CWLS secara koheren (Jucker, 2002).

\section{Gaya Berdonasi Kaum Milenial}

Berdasarkan hasil penelitian Ericsson (2016) dengan melakukan wawancara kepada 4.000 responden yang tersebar di 24 negara dunia. Ditemukan 10 tren consumer lab untuk memprediksi beragam keinginan konsumen, salah satunya dengan adanya perhatian khusus terhadap perilaku generasi millennial. Pergeseran perilaku akan berubah beriringan dengan teknologi. Salah satunya, perilaku Streaming Native yang saat ini sedang populer. Jumlah remaja yang mengonsumsi layanan streaming video sangat banyak. Ericsson mencatat, pada 2011 silam hanya ada sekitar tujuh persen remaja berusia 16 - 19 tahun yang menonton video melalui Youtube. Rata-rata mereka menghabiskan waktu di depan layar perangkat mobile sekitar tiga jam sehari. Angka tersebut melambung empat tahun kemudian menjadi 20 persen. Waktu yang dialokasikan untuk menonton streaming juga meningkat tiga kali lipat. Fakta tersebut membuktikan, perilaku generasi millennial sudah tidak bisa dilepaskan dari menonton video secara daring. Teknologi juga membuat para generasi internet tersebut mengandalkan media sosial sebagai tempat mendapatkan informasi.

Saat ini, media sosial telah menjadi platform pelaporan dan sumber berita utama bagi masyarakat. Tren tersebut sudah terbukti disepanjang 2016 melalui beberapa peristiwa penting, seperti aksi teror bom. Masyarakat benar-benar mengandalkan media sosial untuk mendapatkan informasi terkini dari sebuah peristiwa. The Nielsen Global Survey of E-commerce (2018) juga melakukan penelitian terhadap pergeseran perilaku belanja para generasi internet. Penelitian dilakukan berdasar penetrasi internet di beberapa negara. Nielsen melakukan riset terhadap 30 ribu responden yang memiliki akses internet memadai. Responden tersebut berasal dari 60 negara di Asia Pasifik, Eropa, Amerika Latin dan Utara, serta Timur Tengah. Studi tersebut menggambarkan perilaku generasi akrab internet ini memilih jalur daring untuk meneliti dan membeli beragam produk atau jasa dalam memenuhi kebutuhan sehari-hari. Nielsen mencatat, pertumbuhan penetrasi perangkat mobile di kota-kota besar Indonesia mencapai 88 persen. Kepemilikan perangkat mobile menjadi salah satu faktor paling signifikan terhadap perilaku belanja daring. Berdasarkan riset Nielsen tersebut, Indonesia memiliki peringkat teratas secara global dalam hal penggunaan ponsel pintar untuk belanja daring. Sebanyak 61 persen konsumen memilih berbelanja menggunakan ponsel pintar, dan 38 persen lainnya memilih menggunakan tablet atau perangkat mobile lain. Sementara, 58 persen konsumen lebih memilih menggunakan komputer.

Berdasarkan pemikiran lama berdonasi bukanlah suatu kebutuhan, namun generasi $\mathrm{Z}$ dan milenial sebagai seseorang yang hidup di zaman modern dan era teknologi yang penuh dengan kesibukan kerja dan kegiatan pribadi sudah tidak bisa lagi menilai donasi sebagai sebuah kegiatan selingan. Berdasarkan penelitian, generasi milenial dan $\mathrm{Z}$ merupakan generasi yang selalu ingin terlibat dalam kebaikan secara langsung. Kepedulian dan kepekaan generasi ini terhadap isu-isu sosial jauh lebih tinggi daripada generasi-generasi sebelumnya. Bagi generasi 
milenial dan Z, membantu sesama merupakan suatu hal yang mereka lakukan untuk memenuhi kebutuhan rohani mereka. Era digital yang saat ini terjadi merupakan salah satu faktor yang mendorong hal ini muncul dan terjadi dalam kehidupan. Sebelum era digital, kesadaran beragama setiap individu cenderung muncul di fase middle-aged crisis (45-64 tahun) serta later-life crisis (60 tahun), yang bisa dilihat pada generasi Baby Boomers dan generasi X. Namun saat ini kesadaran beragama pada individu sudah berproses di usia muda, seperti yang dialami generasi milenial dan Z. Hasil riset Varkey Foundation (2019) membuktikan bahwa 93\% responden generasi $Z$ yang ada di Indonesia dengan rentang usia 18-21 tahun memiliki kepercayaan, memegang teguh nilai-nilai agama merupakan salah satu faktor penting yang menjadi kunci kebahagiaan dalam kehidupan mereka. Dalam ajaran agama yang umum dan diketahui oleh setiap manusia adalah konsep berbagi dan membantu sesama apapun itu bentuknya. Salah satu bentuk kebaikan yang saat ini memiliki banyak perantara adalah berdonasi. Jika dilakukan dengan ikhlas, amalan tersebut akan menjadi spiritual saving bagi seseorang, yang mana kebaikannya terhadap sesama akan memperoleh pahala dari Tuhan. Memupuk kebiasaan spiritual saving dipandang perlu dilatih dan dikelola secara serius.

\section{Pemasaran CWLS}

Cash Waqf Linked Sukuk perlu strategi edukasi dan sosialisasi khusus agar bisa diterima oleh masyarakat lebih luas. Group Head Priority Banking Mandiri Syariah, Muhammad Triarso mengatakan CWLS perlu terus disosialisasikan meski masa penawaran sudah berakhir. "Karena masih terbilang baru, masyarakat membutuhkan literasi dan edukasi yang lebih lama mengenai produk berbasis wakaf uang ini," katanya pada Republika.co.id, Senin (23/11). CWLS Ritel seri SWR001 telah mengakhiri masa penawaran pada 20 November 2020. Mandiri Syariah telah memfasilitasi sekitar 900 wakif yang berwakaf melalui produk ini. Mandiri Syariah adalah salah satu yang ditunjuk Pemerintah sebagai salah satu mitra distribusi (midis), bersama dengan BNI Syariah BRI Syariah, dan Bank Muamalat. Triarso mengatakan sukuk wakaf dari seri SWR001 merupakan investasi dana wakaf uang yang mengajak nasabah menyebar kemaslahatan bagi umat. Sehingga, produk ini perlu terus disosialisasikan karena bisa melakukan banyak hal dalam satu kali berwakaf. Sekretaris Perusahaan BRI Syariah, Mulyatno Rachmanto mengatakan CWLS adalah produk yang sangat bagus dan menarik perhatian umat. Namun karena masih perdana, banyak yang belum paham sehingga butuh waktu sosialisasi terus menerus. "Kami confident dengan produknya, hanya perlu lebih banyak sosialisasi saja, ini produk yang bagus," katanya. BRI Syariah telah melakukan beberapa kali sosialisasi pada nasabah secara virtual dan melihat antusiasme. Namun demikian, pertanyaan yang dimiliki nasabah masih tergolong sangat mendasar. Ini berarti peluang literasi masih sangat besar untuk dilakukan ke depan.

\section{Peran Media Sosial dalam Meningkatkan Awareness}

Media sosial dapat dikategorikan sebagai pengaruh eksternal yang berperan dalam faktor yang mempengaruhi seorang investor untuk berinvestasi di sukuk (Khan, dkk., 2020). Khan, dkk., (2020) dalam penelitiannya mengenai faktor yang mempengaruhi minat pembelian sukuk menyebutkan bahwa pengaruh eksternal yakni salah satunya media sosial memberikan peran penting dalam peningkatan pengetahuan mengenai sukuk. Semakin tingginya komunikasi yang terjalin di media tentang sukuk, semakin banyak pula orang yang mempelajarinya dan pada akhirnya akan mempengaruhi niat mereka dalam membeli sukuk. Dengan kata lain, semakin 
tinggi kesadaran tentang CWLS dari jejaring sosial atau melalui media massa, maka semakin tinggi peluang investor untuk berinvestasi di sukuk (Khan, dkk., 2020).

Indonesia, memiliki jumlah pengguna media sosial yang cukup tinggi. Berdasarkan data yang dikutip We are social dan Hootsuite persentase pengguna media sosial di Indonesia mencapai $68,1 \%$ dari total jumlah penduduk di Indonesia dan penggunanya pun didominasi dengan generasi milenial. Di sisi lain, menurut data yang dihimpun dari hasil survei yang dilakukan oleh We are social dan Hootsuite alasan penggunaan media sosial untuk membagikan dan mensupport kegiatan sosial berada di peringkat 16 sebesar 12,5\% secara global. Walaupun tergolong rendah, namun persentase tersebut tetap memberikan peluang besar jika dikalikan dengan jumlah penduduk Indonesia yang menggunakan sosial media terutama kaum milenial dan tetap menunjukkan jumlah yang fantastis. Jika jumlah paparan informasi yang disebarkan tinggi dan tepat sasaran, maka peningkatan awareness untuk CWLS bagi para milenials dapat optimal.

\section{Pembahasan}

Wakaf merupakan salah satu instrumen pendanaan sosial Islam yang kebermanfaatannya bisa berdampak besar bagi pembangunan sosial ekonomi masyarakat. Maka dari itu tidak heran jika banyak penelitian yang berusaha membuktikan pengaruhnya untuk pembiayaan pembangunan infrastruktur negara atau untuk peningkatan kualitas hidup masyarakat terutama pengentasan kemiskinan. Tidak ada pembatasan mengenai siapa saja pihak yang dapat mendapatkan manfaat dari pengelolaannya merupakan salah satu keunggulannya serta keharusan mempertahankan nilai pokok dari harta yang wakif percayakan merupakan karakteristik yang unik dan mencerminkan keberlanjutan dari instrumen satu ini sehingga penggunaannya dapat berlangsung lama atau bahkan tidak terbatas oleh waktu. Dengan potensi yang luar biasa besar tersebut, tentunya inovasi dalam dunia perwakafaan perlu dilakukan.

Cash Waqf Linked Sukuk merupakan salah satu terobosan yang dicetuskan oleh BWI sebagai institusi pusat pengelolaan wakaf di Indonesia. Musari (2016) menyebutkan bahwa kolaborasi antara sukuk dan wakaf ini merupakan suatu inovasi untuk keberlanjutan ekonomi. Apalagi dengan diterbitkannya CWLS ritel baru-baru ini, membuka kesempatan bagi masyarakat untuk ikut andil dalam pembangunan Indonesia. Mengingat pentingnya untuk menemukan sumber baru dari mekanisme keuangan yang ditujukan untuk proyek investasi dan pembangunan yang diarahkan secara sosial. Di sisi lain dengan kehadiran CWLS ini juga merupakan jawaban untuk menciptakan dampak pembangunan yang lebih besar dengan mengintegrasikan keuangan sosial Islam dan keuangan komersial Islam (Musari, 2019).

Berdasarkan berbagai fakta yang diulas sebelumnya, terkait fakta empiris mengenai Indonesia sebagai negara yang masyarakatnya memiliki hobi berdonasi dan didominasi oleh generasi milenial, memberikan peluang besar untuk keberlangsungan CWLS. Kondisi tersebut dapat menjadi dasar untuk menggeser atau mencetuskan gaya berdonasi baru dikalangan milenial yang lebih cerdas dan berkelanjutan melalui keikutsertaan mereka dalam berinvestasi pada CWLS. Didukung pula dengan fakta bahwa masyarakat khususnya generasi milenial cenderung mendonasikan uang mereka melalui lembaga amal, maka bukan hal sulit untuk mengenalkan para generasi milenial suatu sistematika investasi akhirat jangka panjang dan memberikan 
dampak lebih luas ketimbang hanya berkisar pada lingkup terbatas dan sekali habis jika hanya disalurkan melalui konsep infaq atau sedekah saja.

Dengan kondisi yang dapat dikatakan cukup mendukung, nyatanya dalam praktiknya CWLS atau bahkan wakaf dengan terminologi baru yakni wakaf uang pun masih minim diketahui dan disadari oleh masyarakat. Dalam peluncuran CWLS ritel seri SWR001 pihak terkait hanya memanfaatkan cara promosi lama dan menjangkau lingkup konsumen yang terbatas dengan memanfaatkan jaringan nasabah internal yang potensial. Walaupun memang saat itu dibatasi oleh waktu. Namun sosialisasi mengenai hadirnya instrumen CWLS seolah terhenti. Dalam dunia pemasaran penting untuk menggunakan berbagai alat promosi yang tepat sasaran sesuai dengan target market guna menggaungkan suatu produk terutama produk baru agar sampai ke telinga target konsumen. Sebagaimana diketahui dalam ulasan sebelumnya bahwa awareness merupakan tahap awal yang penting dan tidak boleh terlewat guna melanjutkan proses tahap selanjutnya hingga sampai pada titik pengadopsian produk baru atau dalam hal ini tahapan seorang investor memutuskan untuk berinvestasi melalui CWLS.

Menghadapi kendala lemahnya tingkat awareness dari masyarakat mengenai CWLS, maka penulis menyarankan beberapa alternatif berikut :

1. Pengoptimalan penggunaan media sosial untuk meningkatkan e-WOM.

2. Pengoptimalan media sosial sebagai wadah bagi investor yakni generasi milenial untuk mengakses informasi mengenai CWLS. Sebagaimana diketahui bahwa generasi milenial merupakan generasi yang sangat erat dengan internet.

3. Penggunaan influencer untuk menggeser gaya berdonasi yang lebih cerdas dan keberlanjutan melalui CWLS.

\section{Kesimpulan}

Berdasarkan berbagai ulasan di atas, dapat disimpulkan bahwa Indonesia sebagai negara dengan tingkat kedermawanan yang tinggi serta didominasi oleh generasi milenial memberikan peluang bagi CWLS sebagai instrumen investasi sosial yang baru diluncurkan sebagai gaya baru dalam berdonasi. Sebagaimana diketahui bahwa kolaborasi antara wakaf dan sukuk ini dapat memberikan dampak pembangunan yang lebih besar terutama dalam lingkup sosial ekonomi masyarakat Indonesia. Namun disisi lain, peluang tersebut juga disertai kendala berupa rendahnya tingkat literasi mengenai wakaf terutama CWLS. Guna mengatasi kendala tersebut, dalam makalah ini menyarankan pengoptimalan peran media sosial dan infuencer guna meningkatkan kesadaran mengenai betapa besarnya dampak yang dapat diberikan CWLS. Dengan meningkatnya awareness dari para generasi milenial yang berperan sebagai calon investor, dapat mempengaruhi peningkatan minat mereka untuk berdonasi melaui mekanisme investasi pada CWLS. Penelitian ini menjadi dasar untuk pengembangan lanjutan mengenai pentingnya awareness dan bagaimana meningkatkan kesadaran dikalangan milenial atau juga mendalami mengenai faktor-faktor apa saja yang dapat mendukung peningkatan awareness CWLS di kalangan milenial sebagai kelompok masyarakat yang potensial untuk ikut andil di dalamnya. 


\section{Referensi}

Badan Wakaf Indonesia. (2019). Mengenal lebih dekat cash wakaf linked sukuk. Badan wakaf Indonesia. Retrieved from https://www.bwi.go.id/4030/2019/11/20/mengenal-lebihdekat-cash-wakaf-linked-sukuk/

Badan Wakaf Indonesia (2021). Mengenal Wakaf Uang. Badan wakaf Indonesia. Retrieved from https://www.bwi.go.id/mengenal-wakaf-uang/

Barry, T.F., \& Howard, D.J. (1990). A review and critique of the hierarchy of effects in advertising. International Journal of Advertising, 9(2), 121-135.

Bulut, M., \& Korkut, C. (2016). Cash waqfs (CWs) and financing of education at ottoman experience. Paper presented at International Symposium on Waqf and Higher Education, Istanbul.

Chowdhury, M.S.R., Ghazali, M.F., \& Ibrahim, M.F. (2011). Economics of cash Waqf Management in Malaysia: a Proposed Cash Waqf Model for Practitioners and Future Researchers. African Journal of Business Management, 5(30), 12155-12163.

Çizakça, M. (2014). Can There be Innovation in Islamic Finance? Case Study: Esham. Paper presented at the 11th IFSB Summit, Knowledge Sharing Partner Session: "New Markets and Frontiers for Islamic Finance: Innovation and the Regulatory Perimeter", to be convened on May 20th in Mauritus.

Gupta, R. (2021). An Empirical Study of Commerce Students (Undergraduate and Postgraduate) for Insurance Industry in India. Asian Journal of Economics and Banking.

Hutter, K., Hautz, J., Dennhardt, S., \& Fuller, J. (2013). The impact of User Interactions in Social Media on Brand Awareness and Purchase Intention: the Case of MINI on Facebook. Journal of Product \& Brand Management, 342-351.

Jacoby, J. (1984). Perspectives on Information Overload. Journal of Consumer Research, 10(4), 432-435.

Jacoby, J., Szybillo, G.J. \& Busato-Schach, J. (1977). Information acquisition behavior in brand choice situations. Journal of Consumer Research, Vol. 3 No. 4, pp. 209-216.

Kahf, M. (2014). Islamic Economics: The Charitable Sector. Qatar: Ad Dawhah.

Kapferer, J.N. (2008). The New Strategic Brand Management. London: Kogan Page.

Keller, K.L. (2008). Strategic Brand Management: Building, Measuring, and Managing Brand Equity. Upper Saddle River, NJ: Pearson Education.

Kementerian Perencanaan Pembangunan Nasional. (2018). Masterplan Ekonomi Syariah Indonesia 2019-2024: Hasil Kajian Analisis Ekonomi Syariah di Indonesia. Jakarta: Kementerian Perencanaan Pembangunan Nasional/Badan Perencanaan Pembangunan Nasional.

Khan, Safeer Ullah, dkk. (2020). Evaluating Sukuk Investment Intentions in Pakistan from a Social Cognitive Perspective. ISR A International Journal of Islamic Finance. 12(3), 347-365.

Kotler, P. \& Bliemel, F. (2001). Marketing-Management. Stuttgart: Scha“ffer-Poeschel Verlag.

Lavidge, R.J. \& Steiner, G.A. (1961). A model for Predictive Measurements of Advertising Effectiveness. Journal of Marketing, 25(3), 59-62.

Musari K. (2019). The Evolution of Waqf and Sukuk toward Sukuk-Waqf in Modern. Islamic Economy. International Journal of 'Umranic Studies. 2(1), 45-54.

Musari, K. (2016a). Economic Sustainability for Islamic Nanofinance through Sukuk-Waqf Linkage Program (Case Study in Indonesia). International Journal of Islamic Economics and Finance Studies. 
Olshavsky, R.W. \& Granbois, D.H. (1979). Consumer Decision Making: Fact or Fiction?. Journal of Consumer Research, 6(2), 93-100.

Pusat Data Republika. (2016). Mengenal Generasi Millennial. Republika. Retrived from https://www.republika.co.id/berita/koran/inovasi/16/12/26/ois64613-mengenalgenerasi-millennial

Salleh, Che Mohd, M., Razali, S.S., Megat Laksana, N.N., Che Embi, N.A. \& Abdullah, N.I. (2020). Developing a Sustainable Model of Waqf-based Takaful for Flood Victims in Malaysia. Journal of Islamic Accounting and Business Research, 11(9), 1941-1952.

Smith, R.E., Chen, J. \& Yang, X. (2008). The Impact of Advertising Creativity on the Hierarchy of Effects. Journal of Advertising, 37(4), 47-61.

Soeherman, B. (2019). Fun Research: Penelitian Kualitatif dengan design Tbingking (Ebook). Jakarta: PT. Elex Media Komputindo.

Sugiyono. (2017). Metode Penelitian Bisnis Pendekatan kualitatif, kuantitatif, kombinasi dan R\&D. Alfabeta.

Tight, M. (2019). Starting Documentary Research in: Documentary Research in the Social Sciences (Online (E). SAGE Publication.

Vakratsas, D. \& Ambler, T. (1999). How advertising works: what do we really know?. Journal of Marketing, 63(1), 26-43.

We Are Social (2021, April 21). Digital 2021. We Are Social. Retrieved fom https://wearesocial.com/digital-2021

Zaichkowsky, J.L. (1985). Measuring the Involvement Construct. Journal of Consumer Research, $12,341-352$. 
-- This page intentionally left blank --

162 | Al-Awqaf: Jurnal Wakaf dan Ekonomi Islam, Vol. 13, No. 2, Tahun 2020 